\title{
Responses of Six Oil Sunflower (Helianthus annuus L) Genotypes to Post-Anthesis Water Deficit
}

\author{
Nemat M. Hassan ${ }^{1}$, Maaty M. Keshta ${ }^{2}$, Heba T. Ebeed ${ }^{1}$, Olfat S. Hassanin ${ }^{2}$ \\ ${ }^{1}$ Department of Botany and Microbiology, Faculty of Science, Damietta University, New Damietta city, PO 34517 , \\ Egypt. \\ ${ }^{2}$ El-Serw Agricultural Research Station, Damietta, Egypt.
}

Received: 5 June 2017 /Accepted: 28 August 2017

* Corresponding author:eg

\begin{abstract}
A field experiment was carried out to evaluate the responses of six oil sunflower (Helianthus annuus L) genotypes namely; Sakha 53, H(A9XRf6), B11, B12, H(A9XRf8) and B20 to drought stress. Plants were subjected to three levels of water: adequate (control), moderate drought and severe drought Water regime was started directly post anthesis by withholding water during seed-filling stage until complete maturity of seeds. Moderate and severe drought decreased plant height and stem diameter of all genotypes, except B11 and B20 which recorded non-significant decrease in plant height under moderate drought. On the other hand, non-significant effect was observed in leaf area in all genotypes except B12 and H(A9XRf8) where a significant decrease was recorded only under severe drought. Yield components (head diameter, seed yield, 100 seed weight, seed husk \%, seed kernel \%, and oil percentage) responded to drought stress differently according to genotypes. Significant decreases were observed in floral head diameter seed yield, oil percentage and protein content in all genotypes except for the non-significant reduction in seed yield and oil content in Sakha53 and H(A9XRf6) under moderate drought Generally, Skha53 was the most drought-tolerant genotype whereas B11, B12 and B20 exhibited the least tolerance.
\end{abstract}

Keywords: growth, oil, post-anthesis, sunflower, water deficit.

\section{Introduction}

Plants are exposed to various environmental stresses which lead to a number of physiological and biochemical changes. The most usual forms of environmental stress encountered by plants are extreme temperatures, drought and salinity (Ali et. al., 2009). Sunflower (Helianthus annuus L.) is one of the most important sources of vegetable oil due to the high seed content of edible oil (38-50\%) and protein (20-27\%) (Abdel-Motagally and Osman, 2010). Environmental factors during the seed-filling period can widely affect seed yield of oilseed crops (Ali et. al., 2009). Since soil moisture is a main factor for sunflower infection by pathogens such as Sclerotinia sclerotium 
(Purdy, 1979); and at the same time water stress is more harmful during pre-anthesis and anthesis stages (Yegappan et al., 1982); therefore, precise adjustment of water supply during the postflowering period seems a necessary practice for profitable yield of the crop.

Drought stress induces a range of morphological and biochemical responses in plants including alteration of water absorption and nutrient uptake (Shinozaki et al., 2003; Bartels and Sunkar, 2005). The impaired growth and development under the impact of water stress resulted in low yield of seeds and oil in sunflower (Flagella et al., 2002; Soleimanzadeh et al., 2010) as well as low seed yield and protein content of peanut seeds (Amir et al., 2005) and soybean seeds (Foroud et al., 1993). So, the present study was conducted to investigate the effect of post-anthesis water deficit on growth, yield, yield components, oil percentage and protein content of six sunflower genotypes cultivated widely in Egypt.

\section{Materials and Methods}

A field experiment was carried out at El-Serw Agricultural Research Station (ARC) during the growing season of sunflower (long day condtions) to evaluate the growth characters and yield components of six oil sunflower genotypes

(Helianthus annuus L), namely; Sakha 53, H(A9XRf6), B11, B12, H(A9XRf8) and B20 under three levels of water regime. A randomized split plot design with three replications was adopted with water regimes as large plots and genotypes as subplots. Plants were sown in rows planted $0.7 \mathrm{~m}$ apart, with the seeds placed $0.25 \mathrm{~m}$ apart along the row. Seeds of the six genotypes were soaked in water for 4 hours and then germinated in a greenhouse on a clayey soil under field conditions. The plots were furrow-irrigated to ensure uniform growth during the growing season. Super phosphate $\left(100-\mathrm{kg} \mathrm{fed}^{-1}\right)$ and ammonium nitrate $\left(150 \mathrm{Kg} \mathrm{fed}^{-1}\right)$ fertilizers were applied twice; once at vegetative stage $(20 \mathrm{~d}$ after emergence) and the other during the flowering stage (50 d after emergence). All plants were well irrigated every two weeks from emergence until flowering; (this period differed according to the genotype; where it ranged between 50-60 days). After all flower heads had been opened for each genotype, drought treatment started and plots were divided into three groups: one group was left as control and received adequate supply of water by irrigation once every two weeks, that is two irrigations over the treatment period The second group was subjected to moderate drought (irrigated only once) and the third group was subjected to sever drought by withholding water completely Plants were grown under the different water regimes up to complete maturity of seeds (about 30 days post anthesis).

\section{Determination of growth characters and yield components}

Harvest was conducted after complete maturity when the back of the flower heads turned brown and leaves were dry. Five plants were randomly selected from the middle row of each treatment for all genotypes. Growth characters such as plant height, stem diameter were measured Yield and yield components such as head diameter, seed yield plant ${ }^{-1}$, weight of 100 seeds, seed husk $\%$ and seed kernel $\%$, seed yield fed ${ }^{-1}$ and oil yield fed ${ }^{-1}$ were determined.

\section{Determination of total leaf area}

Total leaf area was measured after complete maturity of every leave (leave petiole turned yellow) as described in Casadebaig et al., (2008).

\section{Determination of oil content}

Seeds were oven-dried at $40{ }^{\circ} \mathrm{C}$ for $4 \mathrm{~h}$, using a ventilated oven, up to a moisture content of about $5 \%$, and were then ground with a Warring blender. Four grams of the powder were extracted with petroleum ether $(80 / 90)$ for $16 \mathrm{~h}$ in a Soxhlet system according to AOCS (1993). The oil extract was evaporated in a rotary evaporator at $40{ }^{\circ} \mathrm{C}$ and the weight of oil was recorded.

\section{Determination of seed protein content:}

Protein was extracted from dry powdered seeds with $1 \mathrm{~N} \mathrm{NaOH}$ for $24 \mathrm{~h}$ at $4{ }^{\circ} \mathrm{C}$ The residue was removed by centrifugation $10 \mathrm{~min}$ at $10000 \mathrm{xg}$ and an aliquot $(0.1 \mathrm{ml})$ of the supernatant was then added to $5 \mathrm{ml}$ Coomassie Brilliant Blue dye reagent and mixed well according to the method adopted by Bradford (1976). Optical density was measured at $595 \mathrm{~nm}$ against water blank. Protein concentration was determined from a standard curve using bovine serum albumin (BSA) in the range of $20-100 \mu \mathrm{gml}^{-1}$. 
Statistical Analysis:

The data were subjected to analysis of variance (ANOVA) two-factors with 3 replicates with two errors, one for the main plot treatments and one for subplot treatments. Different letters indicate

significant differences between treatments at $\mathrm{p} \leq$ 0.05 .

\section{Result and discussion}

Table 1: Analysis of variance for the experimented parameters.

\begin{tabular}{|c|c|c|c|c|c|c|c|}
\hline Parameter & Source of Variation & SS & df & MS & $\mathbf{F}$ & P-value & F crit \\
\hline \multirow[t]{3}{*}{ Plant height } & Sample & 48347.37 & 5.00 & 9669.47 & 264.36 & 0.00 & 2.48 \\
\hline & Columns & 19230.22 & 2.00 & 9615.11 & 262.87 & 0.00 & 3.26 \\
\hline & Interaction & 1854.41 & 10.00 & 185.44 & 5.07 & 0.00 & 2.11 \\
\hline \multirow[t]{3}{*}{ Leaf area } & Sample & 18333268.22 & 5.00 & 3666653.64 & 53.48 & 0.00 & 2.48 \\
\hline & Columns & 14140842.33 & 2.00 & 7070421.17 & 103.13 & 0.00 & 3.26 \\
\hline & Interaction & 2239243.44 & 10.00 & 223924.34 & 3.27 & 0.00 & 2.11 \\
\hline \multirow[t]{3}{*}{ Stem diameter } & Sample & 7.26 & 5.00 & 1.45 & 48.38 & 0.00 & 2.48 \\
\hline & Columns & 12.70 & 2.00 & 6.35 & 211.63 & 0.00 & 3.26 \\
\hline & Interaction & 1.35 & 10.00 & 0.14 & 4.51 & 0.00 & 2.11 \\
\hline \multirow[t]{3}{*}{ Head diameter } & Sample & 287.10 & 5.00 & 57.42 & 99.41 & 0.00 & 2.48 \\
\hline & Columns & 439.87 & 2.00 & 219.93 & 380.78 & 0.00 & 3.26 \\
\hline & Interaction & 19.24 & 10.00 & 1.92 & 3.33 & 0.00 & 2.11 \\
\hline \multirow[t]{3}{*}{ Husk\% } & Sample & 198.84 & 5.00 & 39.77 & 23.96 & 0.00 & 2.48 \\
\hline & Columns & 808.20 & 2.00 & 404.10 & 243.51 & 0.00 & 3.26 \\
\hline & Interaction & 126.45 & 10.00 & 12.64 & 7.62 & 0.00 & 2.11 \\
\hline \multirow[t]{3}{*}{ Kernel\% } & Sample & 209.27 & 5.00 & 41.85 & 19.88 & 0.00 & 2.48 \\
\hline & Columns & 913.35 & 2.00 & 456.67 & 216.91 & 0.00 & 3.26 \\
\hline & Interaction & 124.10 & 10.00 & 12.41 & 5.89 & 0.00 & 2.11 \\
\hline \multirow[t]{3}{*}{ Seed yield fed ${ }^{-1}$} & Sample & 8500048.09 & 5.00 & 1700009.62 & 257.60 & 0.00 & 2.48 \\
\hline & Columns & 2925485.48 & 2.00 & 1462742.74 & 221.65 & 0.00 & 3.26 \\
\hline & Interaction & 778794.30 & 10.00 & 77879.43 & 11.80 & 0.00 & 2.11 \\
\hline \multirow[t]{3}{*}{ Seed yield plant ${ }^{-1}$} & Sample & 10207.42 & 5.00 & 2041.48 & 198.44 & 0.00 & 2.48 \\
\hline & Columns & 3306.22 & 2.00 & 1653.11 & 160.69 & 0.00 & 3.26 \\
\hline & Interaction & 628.48 & 10.00 & 62.85 & 6.11 & 0.00 & 2.11 \\
\hline \multirow[t]{3}{*}{100 seeds wt } & Sample & 41.43 & 5.00 & 8.29 & 52.15 & 0.00 & 2.48 \\
\hline & Columns & 52.27 & 2.00 & 26.13 & 164.48 & 0.00 & 3.26 \\
\hline & Interaction & 1.47 & 10.00 & 0.15 & 0.92 & 0.52 & 2.11 \\
\hline \multirow[t]{3}{*}{ oil yield fed ${ }^{-1}$} & Sample & 1435033.66 & 5.00 & 287006.73 & 266.60 & 0.00 & 2.48 \\
\hline & Columns & 697618.29 & 2.00 & 348809.15 & 324.01 & 0.00 & 3.26 \\
\hline & Interaction & 187316.29 & 10.00 & 18731.63 & 17.40 & 0.00 & 2.11 \\
\hline \multirow[t]{3}{*}{ Oil\% } & Sample & 274.62 & 5.00 & 54.92 & 91.20 & 0.00 & 2.48 \\
\hline & Columns & 852.66 & 2.00 & 426.33 & 707.93 & 0.00 & 3.26 \\
\hline & Interaction & 115.07 & 10.00 & 11.51 & 19.11 & 0.00 & 2.11 \\
\hline \multirow[t]{3}{*}{ Seed Protein } & Sample & 5835.17 & 5.00 & 1167.03 & 82.26 & 0.00 & 2.48 \\
\hline & Columns & 111750.40 & 2.00 & 55875.20 & 3938.50 & 0.00 & 3.26 \\
\hline & Interaction & 6324.47 & 10.00 & 632.45 & 44.58 & 0.00 & 2.11 \\
\hline
\end{tabular}

Growth characters:

The results in fig. 1 show that, plant height significantly decreased either by moderate or severe water stress in all genotypes except for
B11and B20 which recoded non-significant difference due to moderate drought.

Similar results were obtained by Riahi Nia, (2003) on sunflower, cotton, and bean. Likely, drought stress led to reduction in water potential of stem 
cell to a lower level needed for cell elongation and consequently, shorter inter nodes and stem height. The decrease of shoot length as a response of decrease in cell elongation resulting from water shortage, led to a decrease of each cell turgor, cell volume and eventually, cell growth (Boyer, 1988). Water stress also leads to blocking up of xylem and phloem vessels, thus hindering any transferring through stem (Lovisolo and Schuber, 1998). Fig.1 also shows that water stress decreased significantly stem diameters in all examined genotypes except B11 and H(A9XRf8) which recoded non-significant difference due to moderate drought. Molze and Klepper, (1973) reported that low water availability causes the reduction of stem diameter due to lower radius growth of stem. On the other hand, nonsignificant effect was observed in leaf area in all sunflower genotypes except B12 and H(A9XRf8) where a significant decrease was recorded with non-significant difference between moderate and severe drought. In agreement with our results, Sankar et. al., (2008) reported that total leaf area in bhindi plants was significantly reduced under drought stress. Drought stress significantly reduced growth of B11 compared to the remaining genotypes whereas, Sakha53 showed the lowest adverse impact by drought stress on the growth parameters.
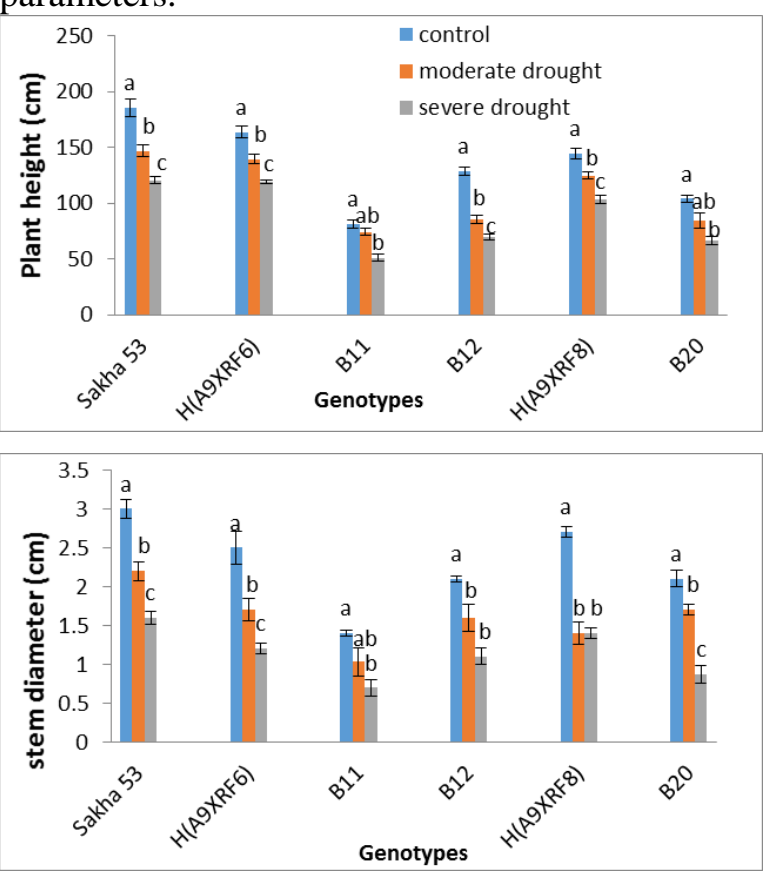

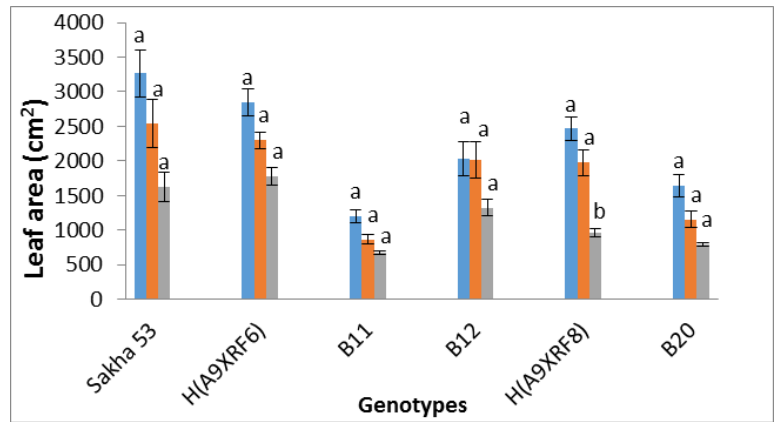

Fig. 1: Changes in plant height, stem diameter and leaf area of six oil sunflower genotypes at harvest (30 days post anthesis) as a result of drought by withholding water during filling stage. Data are means of 3 replicates \pm SE. Different letters indicate significant differences between treatments at $\mathrm{p} \leq 0.05$.

\section{Yield parameters and components:}

Yield characters (head diameter, seed husk \% and seed kernel\%) were mostly affected by water deficit. Generally, head diameter was decreased due to drought in all tested genotypes. The magnitude of decrease was most pronounced with severe drought. Conversely, seed husk\% in all examined genotypes was increased due to drought at the two levels. Similar results were obtained by Yegappan et al., (1982) who indicated that shell weight increased in drought stress conditions either before or after flowering stage. Fig. 2 also shows that, seed kernel \% was significantly decreased by water stress, the increase in drought stress the decrease in seed kernel \%. B11 and H(A9XRf8) kernel \% under moderate stress did not differ significantly from control. The decrease in seed kernel \% in different crops under similar conditions has also been reported by many workers such as (Tahir et al., 2002). These results are in agreement with those obtained by Jabari et al., (2007) and Nezami et al.,_(2008). Hadi et al., (2012) found that deficit irrigation caused significant decrease in sunflower yield and yield components. Generally, water stress leads to reducing photosynthesis activity and induce unbalanced relations between plant hormones and biological processes in the plant organs as a whole (Aminifar et al., 2012). In addition, with decreasing of water absorption, turgidity and cell division decrease and consequently, plant growth decrease (Zaefizadeh et al., 2011). In drought stress conditions ABA hormone increased causing decrease in the activity of IAA and CK hormones which are responsible for cell division and cell elongation (D,andria et al., 1995) 


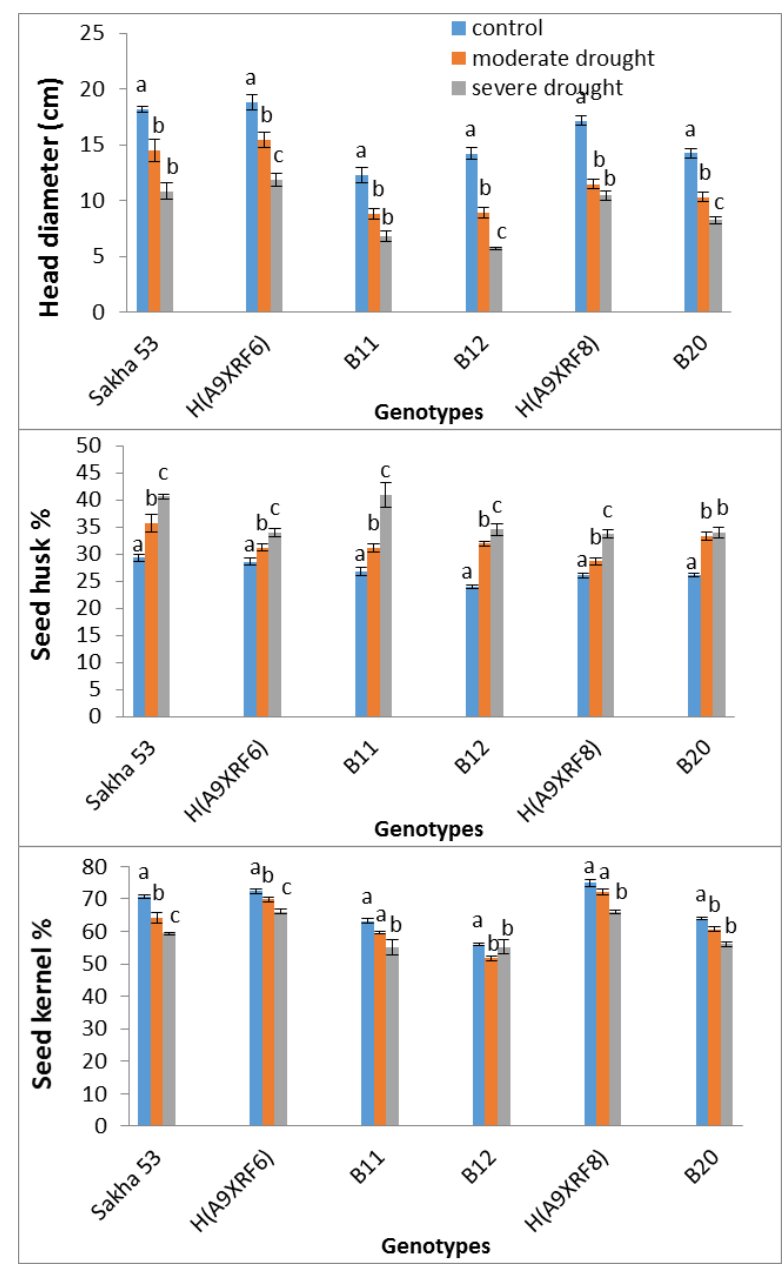

Fig. 2: Changes in head diameter, seed husk \% and seed kernel $\%$ of six oil sunflower genotypes at harvest (30 days post anthesis) as a result of drought by withholding water during filling stage. Data are means of 3 replicates \pm SE. Different letters indicate significant differences between treatments at $p \leq 0.05$.

Similarly, under drought stress all genotypes recorded significant decrease in seed yield/plant as compared to control. Under moderate and severe drought, plants responded as the same manner compared to control. In this investigation, seed yield/fed are reduced due to water stress in all sunflower genotypes (Fig.3). Sakha53, H(A9XRf6) and H(A9XRf8) showed the highest yield in control and stress conditions compared to B11, B20 and B12 which showed the lowest yield and the highest reduction in yield parameters due to stress. The highly positive effect of irrigation on seed yield confirms the key role of supplementary irrigation at critical growth stages, particularly those sensitive to water stress (Quaglietta and d'Andria 1994). The data shown in fig. 3 also cleared that, in comparison with control values, water stress resulted in significant decreases in the weight of 100 seed in all tested genotypes except for Sakha53, B12 and H(A9XRf8) which showed a significant decreas in the weight of 100 seed in response to sever water stress only. The yield loss caused by drought stress could be attributed to an increased rate of flower and pod abortion. Also, disturbed nutrient uptake efficiency and photosynthate product translocation within the plant could lead to yield reduction (Riaz \& Chowdhry 2003).

As general, the present data shows that B11, B12 and B20 produced the lowest oil yield/fed comparing other genotypes. Drought stress caused significant reduction in the oil content of all genotypes as compared to control; the increase in drought stresses the decrease in oil yield (fig. 4). Sakha53 and H(A9XRf6) significantly showed the highest oil \% under stress conditions compared to the other genotypes under the same condition. Similar results were obtained by Zubillaga et al., (2002) and Iqbal et al., (2005). Similarly, Oil yield of sunflower was increased under good irrigation (Flagella et al., 2002).

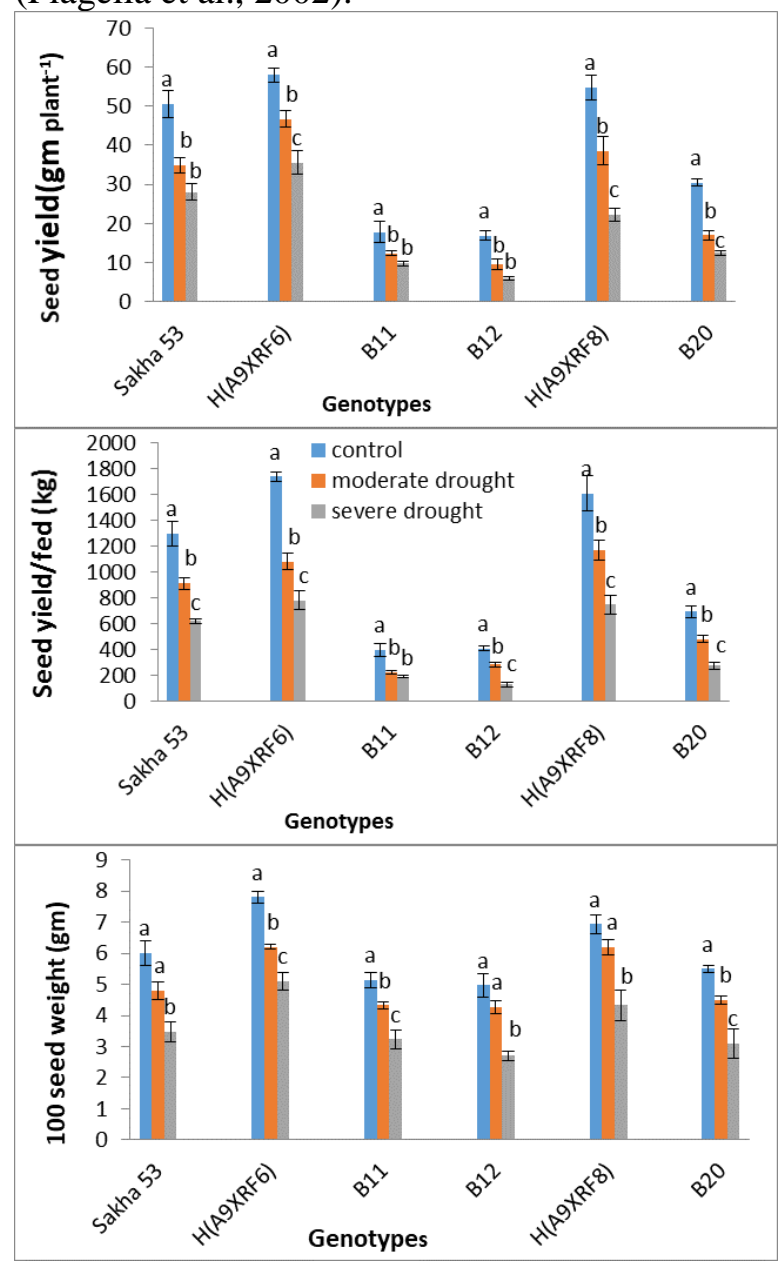

Fig. 3: Changes in seed yield $\mathrm{fed}^{-1}$, seed yield plant ${ }^{1}$ and 100 seed weight of six oil sunflower genotypes at harvest (30 days post anthesis) as a result of drought by withholding water during filling stage. Data are means of 3 replicates \pm SE. Different letters indicate significant differences between treatments at $\mathrm{p} \leq 0.05$. 
Results in fig.4 also show that increasing drought level resulted in a significant decrease in seed protein content as compared to control values. Generally, Sakha53 and H(A9XRf6) significantly showed the highest seed protein content under stress conditions compared to the other genotypes under the same conditions. Amutha et al., (2007) found that proteins are altered in plants growing under water stress compared to plants growing under non-stress conditions. Similar results were obtained by (Baraka 2008 \& Hassan et al., 2011). The reduction in protein content of various plant tissues under stress conditions may be due to the inhibition of transamination process, the increase of proteolysis as well as the decrease of protein synthesis.
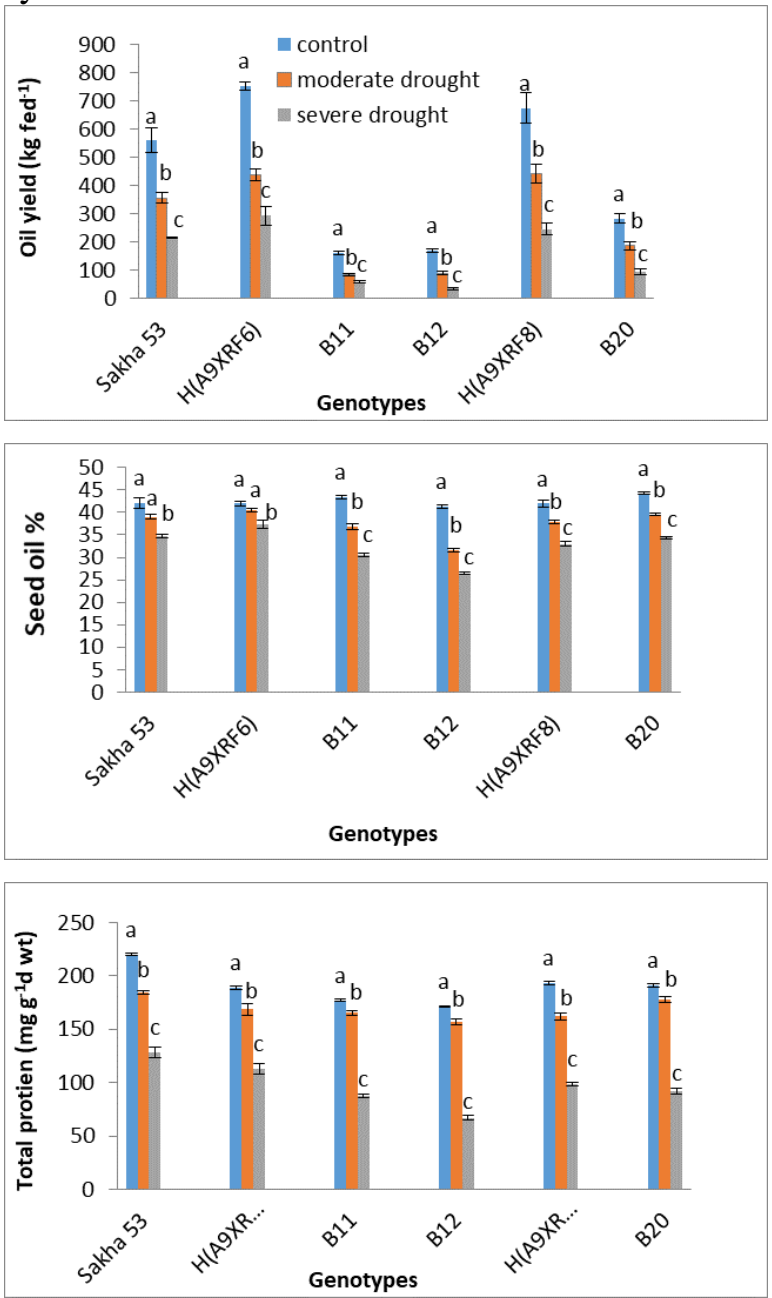

Fig. 4: Changes in oil yieldfed ${ }^{-1}$, seed oil\% and total seed protein of six oil sunflower genotypes at harvest (30 days post anthesis) as a result of drought by withholding water during filling stage. Data are means of 3 replicates \pm SE Different letters indicate significant differences between treatments at $\mathrm{p} \leq 0.05$.

\section{Conclusion}

Overhead irrigation and lack (shortage) of water are very harmful to sunflower plants especially during the seed filling period as they cause infection by pathogens or severe loss in yield respectively. Maximum seed yield would be obtained when the crop received moderate irrigation. Drought stress at seed filling negatively affected the crop growth and yield components. The oil content was decreased due to sever water stress in all genotypes. Sakha53, H(A9XRf6) and H(A9XRf8) genotypes showed better yield and growth in response to drought compared to the other genotypes. However, Sakha53 and H(A9XRf6) showed relatively high seed oil \% and protein content and can be grown in soils where enough irrigation water is not available.

\section{References}

Abdel-Motagally FM. F., \& Osman EA. (2010): Effect of nitrogen and potassium fertilization combination of productivity of two sunflower cultivars under east of El-ewinate conditions. American-Eurasian Journal of Agricultural \& Environmental Science 397-401.

Ali Q., Ashraf M., \& Anwar F. (2009): Physicochemical attributes of seed oil from drought stressed sunflower (Helianthus annuus L.) plants. Grasasy Aceites, 60 (5), 475-481.

Aminifar J., Mohsenabadi GH., Biglouei MH. \& Samiezadeh H. (2012): Effect of deficit irrigation on yield, yield components and phenology of soybean cultivars in Rasht region. Intern. J. Agri. Sci. 2(2): 185-191.

Amutha R., Muthulaksmi S., Baby Rani W., Indira K., \& Mareeswari P. (2007): Studies on biochemical basis of heat tolerance in sunflower (Helianthus annus L.). Res. J. Agric. Biol. Sci. 3: 234-238.

AOCS. (1993): The American Oil Chemists Society Champaign IL.Official methods and recommended practices.

Amir, Y., Benbelkacem, T., Hadni, L., \& Youyou A. (2005): Effect of irrigation and fertilization on the characteristic of peanut seeds cultivated near Tiziouzou. Elect. J. Environ., Agric. Food Chem., 4, 879-885.

Baraka DM. (2008): Osmotic adjustment of wheat grain germination to hyperosmotic saline by nicotine hormone. Res. J. Agric. Biol. Scien., 4: 824- 831 .

Bartels D. \& Sunkars R. (2005). Drought and salt tolerance in plants. Crit. Rev. Plant Sci. 24: 23-58. 
Boyer JS. (1988): Cell enlargement and growth induced water potentials. Physiol. Plant, 73: 311316

Bradford MM. (1976): A rapid and sensitive method for the quantification of microgram quantities of protein utilizing the principle of protein dye binding. Anal. Biochem. 72: 248-54.

Casadebaig P., Debaeke P. \& Lecoeur, J. (2008): Thresholds for leaf expansion and transpiration response to soil water deficit in a range of sunflower genotypes. European Journal of Agronomy, 28: 646-654.

D’Andria R., Chiaranda FQ., Magliulo V., \& Mori M. (1995): Yield and soil water uptake of sunflower sown in spring and summer. Agron. J. 87:11221128 .

Flagella, Z., Rotunno, T., Caterina, R. D., Simone, G. D., \& Caro AD. (2000): Effect of supplementary irrigation on seed yield and oil quality of sunflower (Helianthus annuus L.) grown in a sub-arid environment, in: Proceedings of XV International Sunflower Conference, 139-144, 1, toulouse.

Flagella Z., Rotunno T., Tarantito E., Caterina RD., \& Caro AD. (2002): Changes in seed yield and oil fatty acid composition of high oleic sunflower (Helianthus annuus L.) hybrids in relation to the sowing date and the water regime. Europ. J. Agron., 17, 221-230.

Foroud N., Mundel HH., Saindon G., \& Entz T. (1993): Effect of level and timing of moisture stress on soybean yield, protein and oil responses. Field Crops Research, 31, 195-209.

Hadi H., Khazaei F., Babaei N., Daneshian J. \& Hamidi A. (2012): Evaluation of water deficit on seed size and seedling growth of sunflower cultivars. International Journal of AgriScience Vol. 2(3): 280290.

Hassan NM., El-Sayed A K., Ebeid HT. \& Nemat Alla M M. (2011): Molecular aspects in elevation of sunflower tolerance to drought by boron and calcium foliar sprays Acta Physiol. Plant. 33:593600

Iqbal M. \& Ashraf M. (2005): Changes in growth, photosynthetic capacity and ionic relations in spring wheat (Triticum aestivum L.). Plant Growth Regul., 60: $41-52$

Jabari H., Akbari GA., Daneshian J., Alahdadi I. \& Shahbazian N. (2007): Effect of water deficit stress on agronomic characteristics of sunflower hybrids. Agric Res. Spring 9(1): 13-22

Lovisolo C. \&. Schuber A. (1998): Effects of water stress on vessel size xylem hydraulic conductivity in vitis vinifera L. J. Exp. Bot., 49(321): 693-700.

Molz FJ. \&. Klepper B. (1973): On the mechanism of water stress induced stem deformation. Agron. J., 65: 304-306

Nemat M. Hassan, Zeinab M. El-Bastawisy, Enas G.
Badrana \& Ebtesam M. Hamady (2016): Role of stigmasterol and folic acid in improving the growth and yield of flax under drought. Scien. J. Damietta Fac. Sci. 6(1): 40-48

Nezami A., Khazaei HR., Boroumand Z.\& Hosseini A. (2008): Effects of drought stress and defoliation on sunflower (Helianthus annuus L.) in controlled conditions. Desert, 12: 99-104

Purdy LH (1979): Sclerotinia sclerotiorum: history, diseases and symptomatology, host range, geographic distribution and impact. Phytopathology 69:875-880

Quaglietta CF. \& d'Andria R. (1994): Effect of different irrigation scheduling on yield and water uptake of a spring sunflower crop (Helianthus annus L.). Europ. J. Agron. 3: 53-61.

Riaz R., Chowdhrv M., (2003): Genetic analysis of some economic traits of wheat under drought condition. Asian J. Plant Sci. 2: 790-796.

Riahi Nia SH. (2003): Evaluation of water stress in corn, sunflower, cotton and bean. M.Sc. thesis, of agronomy, Faculty of Agriculture, Ferdowsi University of Mashhad

Sankar B., Jaleel AC., Manivannan P., Kishorekuma A., Somasundaram R.\& Panneerselvam R. (2008): Relative efficacy of water use in five varieties of Abelmoschus esculentus L. Moench. under waterlimited conditions. Colloids and Surfaces B: Biointerfaces, 62: 125- 129.

Shinozaki K., Yamaguchi-Shinozaki K. \& Seki M. (2003): Regulatory network of gene expression in the drought and cold stress responses. Cur. Opin. Plant Biol. 6: 410-417.

Soleimanzadeh H., Habibi D., Ardakani MR., Paknejad F., \& Rejali F. (2010): Response of sunflower (Helianthus annuus L.) to drought stress under different potassium levels. World Appl. Sci. J., 8(4), 443-448.

Tahir MHN., Imran M. \& Hussain MK. (2002): Evaluation of sunflower (Helianthus annuus L) inbred lines for drought tolerance. Intern. J. Agric. Bio. Sci., 3: 398-400.

Zaefizadeh M., Jamaati-e-Somarin S., Zabihi-eMahmoodabad R.\& Khayatnezhad M. (2011): Discriminate analysis of the osmotic stress tolerance of different sub cultivars of durum wheat during germination. Advanc. Environ. Biol. 5(1):74-80

Zubillaga MM., Aristi JP. \& Lavado RS. (2002): Effect of phosphorus and nitrogen fertilization on sunflower (Helianthus annus L) nitrogen uptake and yield. J. Agron. Crop Sci. 188: 267-274.

Yegappan TM., Paton DM., Gates GT. \&Muller WJ. (1982): Water stress in sunflower (Helianthus annuus L.). III. Response of cypsela size. Ann. Bot. 49: 69-75. 


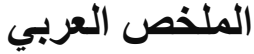

عنوان البحث: استجابة ستة أنماط جينية من نبات دوار الثمس لاجهاد نقص الماء خلال فترة ما بعد

نعمت حسن' ، معاطى قثطة ‘، هبة عبيد'، الفت سعد ' محلية العلوم جامعة دمياط - مصر البحوث الزراعية بالسرو دقهية ـ مصر

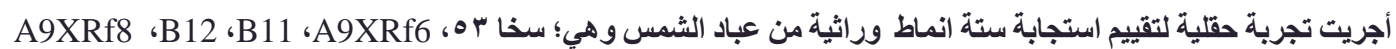

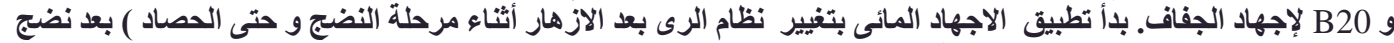

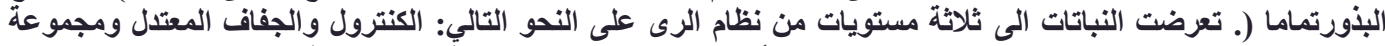

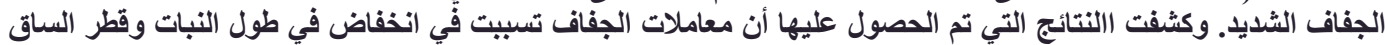

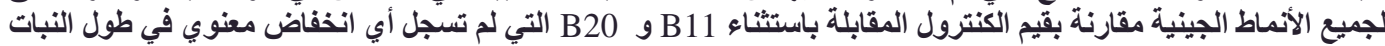

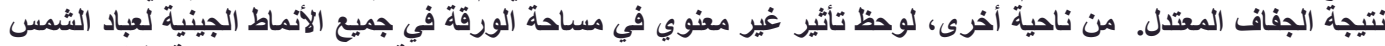

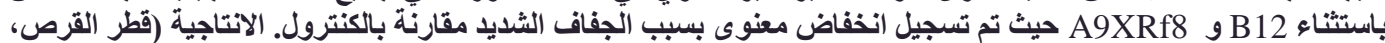

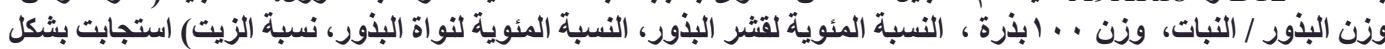

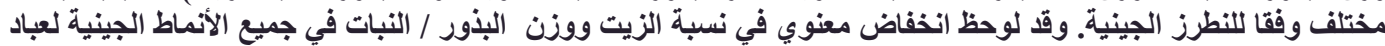

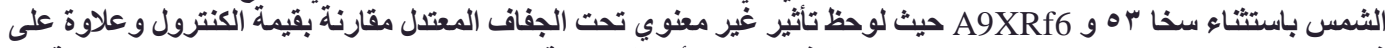

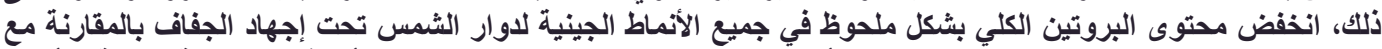

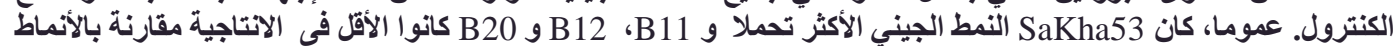

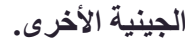

